\title{
Energy and nutrient intakes in relation to sex and socio-economic status among school adolescents in urban Cameroon, Africa
}

\author{
Léonie N Dapi ${ }^{1, *}$, Agneta Hörnell ${ }^{2}$, Urban Janlert ${ }^{1}$, Hans Stenlund ${ }^{1}$ and \\ Christel Larsson ${ }^{2}$ \\ 'Department of Public Health and Clinical Medicine, Epidemiology and Global Health, Umeå University, \\ SE-901 85 Umeå, Sweden: ${ }^{2}$ Department of Food and Nutrition, Umeå University, Umeå, Sweden
}

Submitted 12 January 2010: Accepted 7 October 2010: First published online 6 December 2010

\begin{abstract}
Objective: To assess energy and nutrient intakes and physical activity of adolescents in urban Cameroon according to sex and socio-economic status (SES). Design: Cross-sectional study with adolescents randomly selected from schools in low-, middle- and high-SES areas. Weight and height were measured and information about food intake and physical activity was obtained through repeated individual $24 \mathrm{~h}$ recalls. Under- and over-reporting of energy intake and inadequacy of nutrient intake were assessed.

Setting: Yaoundé, Cameroon.

Subjects: Boys and girls aged 12-16 years ( $n$ 227).

Results: Boys had a lower BMI and reported higher energy expenditures and physical activity levels (PAL) than girls. Under-reporting of energy intake was large among boys and girls regardless of PAL; boys under-reported more than girls. Among those with low PAL, over-reporting of energy intake was common. Over $50 \%$ of boys and girls had protein below the recommendations. The intake of fat varied; $26 \%$ of the adolescents were below and $25 \%$ were above the recommendations. Inadequate intakes of vitamin $\mathrm{B}_{1}$, vitamin $\mathrm{B}_{3}$ and $\mathrm{Fe}$ were more common among girls, while boys more often had inadequate intake of vitamin A. Adolescents with low SES were more likely to be below the recommendations for fat and vitamins $\mathrm{B}_{2}, \mathrm{~B}_{3}, \mathrm{~B}_{6}$ and $\mathrm{B}_{12}$ than those with high SES. Conclusions: A high proportion of boys and girls reported inadequate intakes. However under- and over-reporting were also very common. Boys underreported energy intake more than girls and inadequate nutrient intake was more frequently reported by adolescents with low SES than by those with high SES.
\end{abstract}

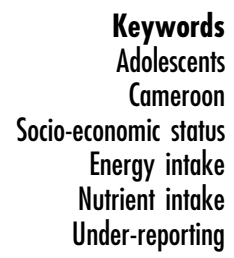

Within the past few decades Cameroon has undergone several socio-economic changes such as an economic crisis from 1986 to 1995, a reduction of public worker salaries in 1993, and currency depreciation in 1994. These events have resulted in inflation, making some traditional food items regularly unaffordable to some people ${ }^{(1)}$. Consequently, many households have switched from consuming traditional staple foods to inexpensive and easily prepared foods and foods that are rich in fat and sugar ${ }^{(1)}$. Furthermore, with a new school schedule implemented in 1993 (previously 07.00-12.00 and 14.00-17.00 hours, presently 08.00-16.00 hours), students stay in school for lunch and snacks between meals. Since there are no school restaurants, food choices for pupils are sandwiches, doughnuts, pastries, chips, candies, chocolates and sweet beverages sold by vendors within the school yard ${ }^{(2)}$. All of these factors have led to a drastic change in the nutritional intake of adolescents, especially in urban Cameroon.

Dietary requirements are high during adolescence because of growth spurts, puberty and cognitive development ${ }^{(3-8)}$. Therefore it is of great importance that adolescents have adequate intakes of energy and micronutrients ${ }^{(4-6,8)}$. The energy adolescents require per day is the highest energy requirement of any age group ${ }^{(9)}$. Ca is especially important for normal growth, to build a strong skeleton and to increase peak bone mass ${ }^{(4)}$. Fe is important for growth and to build muscle mass for both males and females, and even more important for females who have entered puberty ${ }^{(4-6,8)}$. Vitamin A is necessary for normal growth and good functioning of the body ${ }^{(4)}$. $\mathrm{Zn}$ is essential for linear growth, sexual maturation and for the metabolism of 
protein, lipids, carbohydrates, enzymes and nucleic acids $^{(6)}$. B vitamins enhance the immune and nervous systems, keep the skin and muscles healthy, encourage cell growth, and participate in the metabolism of carbohydrates, proteins, fats, minerals and other vitamins ${ }^{(6,10)}$.

In a previous study we found that intakes of meat, vegetables, cereals, milk products and junk food were higher among adolescents in an urban area than in a rural area of Cameroon ${ }^{(11)}$. We also found that the prevalence of underweight and stunting was higher among adolescents with low socio-economic status (SES) than among those with high SES, and that boys were more often underweight and stunted than girls ${ }^{(12)}$. To our knowledge, no study has been published on adolescents' energy and nutrient intakes in Cameroon. The aim of the present study was to assess energy and nutrient intakes and physical activity of adolescents according to sex and SES in urban Cameroon.

\section{Materials and methods}

\section{Study sample}

Boys and girls aged 12-16 years were recruited from three public secondary schools characterized by different socio-economic levels in Yaoundé, the capital city of Cameroon. One school was located in an area characterized by low SES, another in an area with middle SES and the third from an area with high SES. The original sampling design has been described previously ${ }^{(12)}$. One class comprising approximately eighty adolescents was randomly selected from each school. From each class, all students present at the time of data collection were included in the study. In total, 231 adolescents participated. Four adolescents were excluded because of diseases, being out of the age span or inaccurate data. Thus, in total, 227 adolescents completed the cross-sectional study. Permission to carry out the study, ethical clearance and approval were obtained from the Ethical Committee of the Ministry of Public Health of Cameroon. Permission and written consent were obtained from the headmasters of the schools and from each of the adolescents prior to the study.

\section{Protocol}

Each adolescent completed a questionnaire regarding age, sex and SES. The adolescents were classified into three groups (low, middle and high SES) according to the methodology described by the National Institute of Statistics of Cameroon $^{(13)}$. This system classifies people according to district of habitation, equipment at household level, number of rooms, number of persons per room, parental occupation and students' daily pocket money.

The body weight of each adolescent was measured to the nearest $0 \cdot 1 \mathrm{~kg}$ using an electronic scale (model 826 ; Seca, Bradford, UK) in the morning with light clothing and no shoes. Standing height was measured to the closest $0 \cdot 1 \mathrm{~cm}$ using a portable stadiometer (Seca model). Data were collected by personnel who consisted of one public health expert, five school nurses, five assistant nurses, one dietitian and one physician. Prior to the study, the personnel were trained to do anthropometric measurements and to use $24 \mathrm{~h}$ recall interviews.

Three repeated individual interviews lasting about $45 \mathrm{~min}$ each were conducted at the school with the adolescents. The adolescents were asked to recall actual food and drinks consumed and physical activities undertaken during the previous day. The retrospective information about food intake and physical activity covered two weekdays and one weekend day.

\section{Dietary intake assessment}

A colour picture booklet of different portion sizes was developed to help the adolescents estimate the amount of food consumed. The booklet included pictures of thirtytwo common foods such as cassava (Manihot esculenta), plantain (Musa paradisiaca), unripe bananas, potatoes, yam (Dioscorea spp.), cocoyam (Xanthosoma spp.), cassava bread, cassava porridge (fermented cassava), maize porridge, rice, pasta, different kinds of sauces and stews made from green leaves, okok (Gnetum spp.), ndolé (Vernonia amygdalina), gombo (Abelmoshus esculentus), groundnut/ tomatoes, egguci (Cucurbita pepo), beans, beef, chicken and fish. Household measures (spoons, glasses and plates), real food portions and information about the amount of money spent on some foods were also used to estimate the amount of food eaten. For candies, chocolates and biscuits, information about the weight per item was obtained from the labelling. The weight of reported cooked food items eaten at home was measured. Information about ingredients in different meals, product prices and type of fat/oil used was obtained from vendors, restaurants and girls.

The reported food intake was converted into $\mathrm{g} / \mathrm{d}$, and the contents of energy, macronutrients and some micronutrients were calculated using Becel Institution Nutrition Software version 3.0 (BINS; http://www.bins.be). When a specific food item reported eaten by the adolescents was missing in the database, information from the food composition tables of Mali and Africa were used to obtain data about nutritional content ${ }^{(14,15)}$. Laboratory nutrient analyses were done for four main staple foods (cassava bread, cassava porridge, cassava tuber and ripe plantain) by an accredited laboratory (Eurofins, Lidköping, Sweden).

\section{Physical activity assessment}

The adolescents were asked to describe the types and duration of physical activities. Information about intensity of the activity was not collected. Instead, a general metabolic energy turnover (MET) factor was assigned to each type of reported activity and then multiplied with the duration of the activity to calculate the contribution to reported energy expenditure $\left(\mathrm{EE}_{\mathrm{rep}}\right)^{(16,17)}$. $\mathrm{EE}_{\mathrm{rep}}$ was 
calculated as the sum of the energy expenditure from each activity conducted during $24 \mathrm{~h}$, divided by $24 \mathrm{~h}$ and multiplied by the calculated basal metabolic rate $\left(\mathrm{BMR}_{\mathrm{cal}}\right)$ for each individual: $\mathrm{EE}_{\text {rep }}=\left(\right.$ sum EE/24) $\times \mathrm{BMR}_{\mathrm{cal}}$. To obtain $\mathrm{BMR}_{\mathrm{cal}}$ for each adolescent, the Schofield equation based on sex, age, individual body weight and height was used $^{(6,17)}$. A physical activity level $\left(\mathrm{PAL}=\mathrm{EE}_{\mathrm{rep}} / \mathrm{BMR}_{\mathrm{cal}}\right)$ was calculated for each adolescent and was thereafter used to classify the adolescent as having low $(<1 \cdot 675$ for boys, $<1.625$ for girls), moderate (1.675-1.925 for boys, $1 \cdot 625-1.875$ for girls) or high $(>1.925$ for boys, $>1.875$ for girls) PAL, according to the cut-off value described by FAO/WHO/United Nations University ${ }^{(17)}$. Physical activity was assessed by calculation of PAL in order to identify under- and over-reporters of energy intake.

\section{Identifying under- and over-reporting of reported energy intake}

In order to identify under- and over-reporting of reported energy intake $\left(\mathrm{EI}_{\mathrm{rep}}\right)$, Goldberg's cut-off method was used and confidence limits (CL) of agreement between $\mathrm{EI}_{\mathrm{rep}}: \mathrm{BMR}_{\mathrm{cal}}$ and PAL were calculated ${ }^{(6,18)}$. Adolescents with an $\mathrm{EI}_{\text {rep }}: \mathrm{BMR}_{\mathrm{cal}}$ ratio below the lower $\mathrm{CL}$ were regarded as under-reporting and those with a ratio above the upper CL as over-reporting food intake. The equation for calculating the 95\% CL cut-off for each PAL group (low, moderate, high) is:

$$
\mathrm{EI}_{\mathrm{rep}}: \mathrm{BMR}_{\mathrm{cal}}=\mathrm{PAL} \times \exp \left[\mathrm{SD} \times\left(\frac{S / 1000}{\sqrt{n}}\right)\right] .
$$

In the above equation, PAL is the mean PAL for each PAL group calculated from the reported physical activity for three days. SD (standard deviation) is 2 for the $95 \%$ $\mathrm{CL}^{(6,18)} . S$ is the factor that accounts for the variation in EI, BMR and PAL, given by

$$
S=\sqrt{\frac{\left(\mathrm{CV}_{\mathrm{wEI}}\right)^{2}}{d}+\left(\mathrm{CV}_{\mathrm{wB}}\right)^{2}+\left(\mathrm{CV}_{\mathrm{tP}}\right)^{2}},
$$

while $n$ is the number of subjects in the PAL group. $\mathrm{CV}_{\mathrm{wEI}}$ $(23 \%)$ is the within-subject CV in EI; $\mathrm{CV}_{\mathrm{wB}}(8.5 \%)$ is the $\mathrm{CV}$ of estimated BMR compared with measured BMR; $\mathrm{CV}_{\mathrm{tP}}$ is the total variation in PAL $(15 \%)$; and $d(=3)$ is the number of days of dietary assessment ${ }^{(18)}$.

\section{Data and statistical analyses}

The statistical analyses were performed using the SPSS statistical software package version 15 (SPSS Inc., Chicago, IL, USA) and the level of significance was set at $P<0.05$. Means with standard deviations and medians with 25 th -75 th percentiles are used to present data. Age, weight, height, $\mathrm{BMI}, \mathrm{BMR}_{\mathrm{cal}}, \mathrm{EI}_{\mathrm{rep}}, \mathrm{EE}_{\mathrm{rep}}, \mathrm{EI}_{\mathrm{rep}}: \mathrm{BMR}_{\mathrm{cal}}, \mathrm{PAL}, \mathrm{EI}_{\text {rep }}: \mathrm{EE}_{\mathrm{rep}}$, protein, carbohydrate and fat were normally distributed. Distributions of fibre, vitamins $\mathrm{A}, \mathrm{B}_{1}, \mathrm{~B}_{2}, \mathrm{~B}_{3}, \mathrm{~B}_{6}, \mathrm{~B}_{12}$ and $\mathrm{C}$, folate, $\mathrm{Ca}, \mathrm{Fe}$ and $\mathrm{Zn}$ were skewed. Differences between boys and girls, and between SES groups, were analysed using multivariate ANOVA.
The proportions of adolescents who under- and overreported EI were calculated and differences between PAL groups were analysed using the $\chi^{2}$ test.

The Acceptable Macronutrient Distribution Range (AMDR), Recommended Dietary Allowance (RDA) and Estimated Average Requirement (EAR) were used to determine the adequacy of nutrient intakes (for macronutrients, expressed as percentage below or above the AMDR; for micronutrients, as percentage below the EAR, between the EAR and the RDA, and above the RDA $)^{(6,19-21)}$. AMDR is defined as the range of intakes for a particular energy source associated with reduced risk of chronic diseases while providing adequate levels of essential nutrients ${ }^{(6)}$. The AMDR is $10-30 \%, 45-65 \%$ and $25-35 \%$ of total energy (\%E) for protein, carbohydrate and fat, respectively. The RDA is the average daily nutrient intake level estimated to meet the requirement of nearly all healthy individuals of a particular life stage and sex. The EAR is the average daily nutrient intake level estimated to meet the nutrient requirement of half the healthy individuals of a particular life stage and sex ${ }^{(21)}$. The EAR for adolescents is derived from a formula based on the EAR for adults, weight of the adolescents, weight of adults and a growth factor:

$$
\begin{aligned}
\text { EAR }_{\text {adolescent }}= & \text { EAR }_{\text {adult }} \times\left(\text { weight }_{\text {adolescent }} / \text { weight }_{\text {adult }}\right)^{0.75} \\
& \times(1-\text { growth factor }) .
\end{aligned}
$$

The EAR for adults is equal to the RDA divided by 1.3

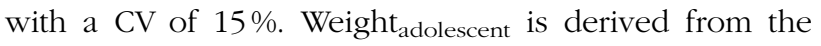
present study; $45.0 \mathrm{~kg}$ for boys and $51.3 \mathrm{~kg}$ for girls. The WHO reference weight of adults, $65 \mathrm{~kg}$ for men and $55 \mathrm{~kg}$ for women ${ }^{(20)}$, is used as weight adult $_{\text {in the formula, and }}$ the growth factor is $15 \%{ }^{(21)}$. Differences in the proportions between adolescents below and above requirements for protein, carbohydrate and fat, as well as for vitamins and minerals, were analysed using binary logistic regression and $\chi^{2}$ tests. Correlations between energy intake, protein, carbohydrate, fat, vitamins and minerals were investigated.

\section{Results}

In total, 108 boys and 119 girls participated in the present study, with a mean age of $13 \cdot 3$ (SD 1.0) v. $13 \cdot 5$ (SD 1.0) years, respectively (Table 1 ). Boys had significantly lower body weight, $\mathrm{BMI}$ and $\mathrm{EI}_{\text {rep }}: \mathrm{EE}_{\text {rep }}$ than girls. On the other hand, $\mathrm{BMR}_{\mathrm{cal}}, \mathrm{EE}_{\mathrm{rep}}$ and PAL were significantly higher in boys than girls.

Twenty-three per cent of the adolescents were regarded as having acceptable reported energy intake (as calculated from Table 2). Boys under-reported energy intake significantly more often than girls, who were more likely to over-report $(P=0 \cdot 016)$. Over-reporting of energy intake was common among the adolescents with low and moderate PAL (Table 2). 
Table 1 Characteristics of the study sample by sex and socio-economic status (SES): adolescents aged 12-16 years, urban Cameroon

\begin{tabular}{|c|c|c|c|c|c|c|c|c|c|c|c|c|c|c|}
\hline & \multirow{2}{*}{\multicolumn{2}{|c|}{ All $(n$ 227) }} & \multicolumn{5}{|c|}{ Sex } & \multicolumn{7}{|c|}{ SES } \\
\hline & & & \multicolumn{2}{|c|}{ Boys ( $n$ 108) } & \multicolumn{2}{|c|}{ Girls (n 119) } & \multirow[b]{2}{*}{$P_{\text {Sex }}$} & \multicolumn{2}{|c|}{ Low (n 98) } & \multicolumn{2}{|c|}{ Middle ( $n$ 105) } & \multicolumn{2}{|c|}{ High ( $n$ 28) } & \multirow[b]{2}{*}{$P_{\mathrm{SES}}$} \\
\hline & Mean & SD & Mean & SD & Mean & SD & & Mean & SD & Mean & SD & Mean & SD & \\
\hline Age (years) & $13 \cdot 5$ & $1 \cdot 0$ & $13 \cdot 3$ & $1 \cdot 0$ & $13 \cdot 5$ & $1 \cdot 0$ & $0 \cdot 169$ & $13 \cdot 6$ & $11 \cdot 0$ & $13 \cdot 4$ & $1 \cdot 0$ & $13 \cdot 1$ & 0.9 & 0.037 \\
\hline Height $(\mathrm{cm})$ & $156 \cdot 7$ & $8 \cdot 7$ & $155 \cdot 7$ & $10 \cdot 7$ & $157 \cdot 6$ & $6 \cdot 2$ & $0 \cdot 107$ & $156 \cdot 3$ & 8.9 & $157 \cdot 2$ & $8 \cdot 6$ & $157 \cdot 0$ & $8 \cdot 5$ & 0.838 \\
\hline Weight (kg) & $48 \cdot 3$ & $9 \cdot 1$ & $45 \cdot 0$ & $9 \cdot 1$ & $51 \cdot 3$ & $8 \cdot 1$ & $<0.001$ & $48 \cdot 3$ & $9 \cdot 0$ & $48 \cdot 6$ & $9 \cdot 6$ & $47 \cdot 5$ & $8 \cdot 1$ & $0 \cdot 874$ \\
\hline BMI $\left(\mathrm{kg} / \mathrm{m}^{2}\right)$ & $19 \cdot 6$ & $2 \cdot 7$ & $18 \cdot 4$ & $2 \cdot 3$ & $20 \cdot 6$ & $2 \cdot 7$ & $<0.001$ & $19 \cdot 7$ & $2 \cdot 5$ & $19 \cdot 6$ & $3 \cdot 0$ & $19 \cdot 2$ & $2 \cdot 4$ & 0.659 \\
\hline $\mathrm{BMR}_{\mathrm{cal}}(\mathrm{kJ})$ & 5782 & 517 & 5908 & 638 & 5669 & 341 & $<0.001$ & 5794 & 555 & 5774 & 487 & 5770 & 511 & 0.911 \\
\hline $\mathrm{BMR}_{\mathrm{cal}}(\mathrm{kcal})$ & 1383 & 124 & 1413 & 153 & 1356 & 81 & & 1385 & 133 & 1381 & 116 & 1380 & 122 & \\
\hline $\mathrm{EI}_{\text {rep }}(\mathrm{kJ})$ & 9724 & 2494 & 9849 & 2883 & 9611 & 2595 & 0.445 & 9648 & 2519 & 9734 & 2363 & 9946 & 2601 & 0.764 \\
\hline $\mathrm{EI}_{\text {rep }}(\mathrm{kcal})$ & 2324 & 596 & 2354 & 569 & 2297 & 620 & & 2306 & 424 & 2327 & 589 & 2377 & 622 & \\
\hline $\mathrm{El}_{\mathrm{rep}}: \mathrm{BMR}_{\mathrm{cal}}$ & $1 \cdot 68$ & 0.44 & 1.67 & 0.42 & $1 \cdot 69$ & 0.47 & 0.763 & $1 \cdot 66$ & 0.43 & 1.69 & 0.45 & $1 \cdot 74$ & 0.50 & 0.695 \\
\hline $\mathrm{EE}_{\text {rep }}(\mathrm{kJ})$ & 9725 & 1744 & 10500 & 2035 & 9038 & 1041 & $<0.001$ & 9835 & 1772 & 9637 & 1540 & 9682 & 2305 & 0.875 \\
\hline $\mathrm{EE}_{\text {rep }}$ (kcal) & 2327 & 417 & 2512 & 487 & 2162 & 249 & & 2353 & 424 & 2327 & 589 & 2316 & 551 & \\
\hline $\mathrm{PAL}\left(\mathrm{EE}_{\mathrm{rep}} / \mathrm{BMR}_{\mathrm{cal}}\right)$ & $1 \cdot 68$ & 0.24 & $1 \cdot 77$ & 0.27 & $1 \cdot 59$ & $0 \cdot 15$ & $<0.001$ & $1 \cdot 69$ & $0 \cdot 24$ & $1 \cdot 66$ & 0.21 & $1 \cdot 66$ & 0.28 & 0.809 \\
\hline $\mathrm{EI}_{\text {rep }}: \mathrm{EE}_{\mathrm{rep}}$ & $1 \cdot 02$ & $0 \cdot 30$ & 0.96 & $0 \cdot 27$ & $1 \cdot 07$ & 0.32 & 0.006 & 0.99 & 0.28 & $1 \cdot 02$ & 0.28 & $1 \cdot 09$ & 0.42 & 0.351 \\
\hline Protein $(\mathrm{g})$ & 58 & 19 & 59 & 19 & 57 & 19 & $0 \cdot 405$ & 56 & 19 & 59 & 19 & 59 & 18 & 0.467 \\
\hline Protein (\%E) & 10 & 2 & 10 & 2 & 10 & 2 & 0.672 & 10 & 2 & 10 & 2 & 10 & 1 & 0.611 \\
\hline Fat (g) & 76 & 23 & 76 & 22 & 76 & 24 & 0.980 & 72 & 22 & 77 & 24 & 85 & 23 & 0.023 \\
\hline Fat $(\% \mathrm{E})$ & 30 & 7 & 30 & 6 & 31 & 8 & 0.207 & 29 & 7 & 31 & 7 & 33 & 7 & 0.068 \\
\hline Carbohydrate (g) & 324 & 101 & 331 & 97 & 317 & 104 & 0.265 & 325 & 103 & 323 & 102 & 321 & 92 & 0.994 \\
\hline Carbohydrate (\%E) & 60 & 7 & 60 & 6 & 59 & 8 & 0.251 & 61 & 8 & 59 & 7 & 57 & 7 & 0.058 \\
\hline Fibre $(\mathrm{g})^{\star}$ & 31 & 15 & 33 & 16 & 30 & 13 & 0.076 & 31 & 14 & 31 & 14 & 31 & 15 & 0.924 \\
\hline Fibre $(\mathrm{g} / \mathrm{MJ})$ & $3 \cdot 3$ & $1 \cdot 4$ & $3 \cdot 4$ & 1.5 & $3 \cdot 1$ & $1 \cdot 2$ & 0.149 & $3 \cdot 4$ & $1 \cdot 4$ & $3 \cdot 2$ & $1 \cdot 4$ & $3 \cdot 2$ & $1 \cdot 2$ & 0.900 \\
\hline
\end{tabular}

$\mathrm{BMR}_{\text {cal }}$, basal metabolic rate calculated; $\mathrm{EI}_{\mathrm{rep}}$, energy intake reported; $\mathrm{EE}_{\mathrm{rep}}$, energy expenditure reported; PAL, physical activity level, \%E, percentage of energy.

Multivariate ANOVA was used to test for a difference between boys and girls or between SES groups adjusted by SES and sex, respectively.

${ }^{*}$ Median with 25th-75th percentile for fibre in grams (skewed variable): 29 (22-40) boys, 27 (21-39) girls, 28 (22-39) low SES, 28 (21-39) middle SES, 28 (20-40) high SES. 
Table 2 Under- and over-reporting of energy intake among study sample using Goldberg's cut-off*: adolescents aged 12-16 years, urban Cameroon

\begin{tabular}{|c|c|c|c|c|c|c|c|c|c|c|c|c|c|c|c|}
\hline & \multicolumn{7}{|c|}{ Boys (n 102) } & \multicolumn{8}{|c|}{ Girls (n 115) } \\
\hline & \multicolumn{6}{|c|}{ PAL category } & & \multicolumn{6}{|c|}{ PAL category } & \multirow[b]{3}{*}{$P$ value } & \multirow[b]{3}{*}{$P$ values } \\
\hline & \multicolumn{2}{|c|}{ Low } & \multicolumn{2}{|c|}{ Moderate } & \multicolumn{2}{|c|}{ High } & \multirow[b]{2}{*}{$P$ valuet } & \multicolumn{2}{|c|}{ Low } & \multicolumn{2}{|c|}{ Moderate } & \multicolumn{2}{|c|}{ High } & & \\
\hline & $n$ & $\%$ & $n$ & $\%$ & $n$ & $\%$ & & $n$ & $\%$ & $n$ & $\%$ & $n$ & $\%$ & & \\
\hline Under-reporters & 16 & 39 & 20 & 49 & 15 & 75 & 0.013 & 23 & 30 & 10 & 32 & 6 & 75 & 0.015 & 0.051 \\
\hline Acceptable reporters & 10 & 24 & 10 & 24 & 4 & 20 & & 14 & 19 & 9 & 29 & 2 & 25 & & \\
\hline Over-reporters & 15 & 37 & 11 & 27 & 1 & 5 & & 39 & 51 & 12 & 39 & 0 & 0 & & \\
\hline
\end{tabular}

PAL, physical activity level.

*Differences between PAL categories and between boys and girls were analysed using the $\chi^{2}$ test.

tThe proportion of under-reporters was significantly higher in boys with high PAL $v$. those with low PAL; the proportion of over-reporters was significantly higher in boys with low PAL $v$. those with high PAL.

$\ddagger$ The proportion of under-reporters was significantly higher in girls with high PAL $v$. those with low PAL; the proportion of over-reporters was significantly higher in girls with low PAL $v$. those with high PAL.

$\S$ The proportion of under-reporters was significantly higher in girls with high PAL $v$. those with moderate PAL; the proportion of over-reporters almost met statistical significance in girls with moderate PAL $v$. those with high PAL.

Table 3 Proportion (\%) below or above the Acceptable Macronutrient Distribution Range for protein (10-30\%E), carbohydrate (45-65\%E) and fat $(25-35 \% E)$ by sex and socio-economic status (SES): adolescents aged 12-16 years, urban Cameroon

\begin{tabular}{|c|c|c|c|c|c|c|c|c|}
\hline \multirow[b]{2}{*}{ Macronutrient } & \multirow[b]{2}{*}{$\begin{array}{c}\text { Total } \\
(n \text { 227) }\end{array}$} & \multicolumn{3}{|c|}{ Sex } & \multicolumn{4}{|c|}{ SES } \\
\hline & & $\begin{array}{c}\text { Boys } \\
(n \text { 108) }\end{array}$ & $\begin{array}{c}\text { Girls } \\
(n \text { 119) }\end{array}$ & $P_{\text {Sex }}$ & $\begin{array}{l}\text { Low } \\
(n 94)\end{array}$ & $\begin{array}{l}\text { Middle } \\
(n \text { 105) }\end{array}$ & $\begin{array}{l}\text { High } \\
(n 28)\end{array}$ & $P_{\mathrm{SES}}$ \\
\hline \multicolumn{9}{|l|}{ Protein } \\
\hline$<10 \% \mathrm{E}$ & 55 & 57 & 54 & $0.653^{*}$ & 58 & 52 & 54 & $0.691^{*}$ \\
\hline$>30 \% E$ & 0 & 0 & 0 & - & 0 & 0 & 0 & - \\
\hline \multicolumn{9}{|l|}{ Fat } \\
\hline$<25 \% \mathrm{E}$ & 26 & 27 & 25 & $0.788^{*}$ & 32 & 24 & 11 & $0.038^{*}$ \\
\hline$>35 \% \mathrm{E}$ & 25 & 24 & 27 & $0 \cdot 696^{*}$ & 19 & 28 & 39 & $0.030 *$ \\
\hline \multicolumn{9}{|l|}{ Carbohydrate } \\
\hline$<45 \% \mathrm{E}$ & 7 & 4 & 10 & $0.075^{\star}$ & 6 & 7 & 11 & $0.458^{*}$ \\
\hline$>65 \% \mathrm{E}$ & 11 & 9 & 12 & $0.544^{*}$ & 12 & 9 & 11 & $0.890^{*}$ \\
\hline
\end{tabular}

$\% \mathrm{E}$, percentage of energy.

${ }^{*}$ Differences between boys and girls and between SES groups were analysed using binary logistic regression.

Up to $55 \%$ of the adolescents had an intake of protein below 10\%E (Table 3). Regarding fat, one-quarter of the adolescents had fat intake below $25 \% \mathrm{E}$ and one-quarter above $35 \%$ E. Girls had a significantly lower intake of vitamin $\mathrm{B}_{1}$ than boys (Table 4). The proportion with intake below the EAR was larger among girls for vitamins $\mathrm{B}_{1}$ and $\mathrm{B}_{3}$ as well as Fe compared with boys (Fig. 1). The difference was largest for $\mathrm{Fe}$, with a tenfold difference in the proportion below the EAR. A larger proportion of boys than girls had an intake of vitamin A below the RDA.

The adolescents with low SES were more likely to be below $25 \% \mathrm{E}$ for fat than those with high SES; those with high SES were more likely to be above $35 \% \mathrm{E}$ than those with low SES (Table 3). Furthermore, a statistically significant lower fat intake was found among adolescents with low SES compared with those with middle and high SES (Table 1). Adolescents with low SES were three times more likely to have low fat intake than those with high SES (Table 3). When looking at micronutrient intakes, adolescents with low SES had significantly lower median intakes of vitamins $B_{2}$ and $B_{12}$ than those with high SES
(Table 4). Vitamin $\mathrm{B}_{12}$ intake in the low-SES group was half to one-third that in the middle- and high-SES groups (Table 4). The adolescents with low SES were significantly more likely to be below the EAR for vitamins $\mathrm{B}_{2}, \mathrm{~B}_{3}, \mathrm{~B}_{6}$ and $B_{12}$ than those with high SES (Fig. 2). There was a tendency for folate to be lower among the adolescents with low SES $v$. those with high SES. The proportions with intake below the EAR, within the EAR and RDA, and above the EAR remained almost the same when only acceptable reporters ( $n$ 49) were included in the analyses.

Boys were more likely to be in the moderate and high PAL groups than girls (Table 2). The mean sleeping duration of the adolescents was $9 \mathrm{~h}$. Overall, girls spent more time on low-intensity activities such as doing homework, household activities (cooking, cleaning, washing, doing dishes), sitting, watching television, going by car and praying, while boys spent more time playing football and doing other sport activities. Boys spent more time playing football while girls spent more time on cooking $(P<0 \cdot 001)$. Sixty-six per cent of boys $v .10 \%$ of girls reported playing football, while $12 \%$ of boys $v .42 \%$ 
Table 4 Intakes of micronutrients (median with P25-P75, mean with standard deviation) by sex and socio-economic status (SES): adolescents aged 12-16 years, urban Cameroon

\begin{tabular}{|c|c|c|c|c|c|c|c|c|c|c|c|c|c|c|c|}
\hline \multirow[b]{3}{*}{ Micronutrient } & & \multirow{2}{*}{\multicolumn{2}{|c|}{ Total (n 227) }} & \multicolumn{5}{|c|}{ Sex } & \multicolumn{7}{|c|}{ SES } \\
\hline & & & & \multicolumn{2}{|c|}{ Boys ( $n$ 108) } & \multicolumn{2}{|c|}{ Girls (n 119) } & & \multicolumn{2}{|c|}{ Low ( $n$ 94) } & \multicolumn{2}{|c|}{ Middle ( $n$ 105) } & \multicolumn{2}{|c|}{ High (n 28) } & \multirow[b]{2}{*}{$P_{\mathrm{SES}}$} \\
\hline & & $\begin{array}{c}\text { Median or } \\
\text { Mean }\end{array}$ & $\begin{array}{l}\mathrm{P} 25-\mathrm{P} 75 \\
\quad \text { or SD }\end{array}$ & $\begin{array}{l}\text { Median or } \\
\text { Mean }\end{array}$ & $\begin{array}{l}\mathrm{P} 25-\mathrm{P} 75 \\
\quad \text { or SD }\end{array}$ & $\begin{array}{l}\text { Median or } \\
\text { Mean }\end{array}$ & $\begin{array}{l}\mathrm{P} 25-\mathrm{P} 75 \\
\quad \text { or SD }\end{array}$ & $P_{\text {Sex }}$ & $\begin{array}{l}\text { Median or } \\
\text { Mean }\end{array}$ & $\begin{array}{l}\mathrm{P} 25-\mathrm{P} 75 \\
\text { or SD }\end{array}$ & $\begin{array}{l}\text { Median or } \\
\text { Mean }\end{array}$ & $\begin{array}{l}\mathrm{P} 25-\mathrm{P} 75 \\
\quad \text { or SD }\end{array}$ & $\begin{array}{l}\text { Median or } \\
\text { Mean }\end{array}$ & $\begin{array}{l}\mathrm{P} 25-\mathrm{P} 75 \\
\quad \text { or SD }\end{array}$ & \\
\hline Vitamin A & Median, P25-P75 & 879 & 451-1299 & $\begin{array}{l}779 \\
853\end{array}$ & $346-1233$ & 945 & 595-1333 & $0 \cdot 176$ & $\begin{array}{l}826 \\
885\end{array}$ & 410-1287 & $\begin{array}{l}879 \\
927\end{array}$ & $\begin{array}{l}539-1301 \\
57 ?\end{array}$ & $\begin{array}{l}878 \\
907\end{array}$ & 439-1331 & 0.917 \\
\hline $\begin{array}{c}(\mu \mathrm{g}) \\
\text { Vitamin } \mathrm{B}_{1}\end{array}$ & $\begin{array}{l}\text { Mean, SD } \\
\text { Median, P25-P75 }\end{array}$ & $\begin{array}{r}907 \\
0.6\end{array}$ & $\begin{array}{c}579 \\
0 \cdot 5-0 \cdot 8\end{array}$ & $\begin{array}{r}853 \\
0.7\end{array}$ & $\begin{array}{c}605 \\
0.5-0.9\end{array}$ & $\begin{array}{l}956 \\
0.6\end{array}$ & $\begin{array}{c}554 \\
0 \cdot 5-0 \cdot 8\end{array}$ & 0.011 & $\begin{array}{r}885 \\
0.6\end{array}$ & $\begin{array}{c}600 \\
0 \cdot 5-0 \cdot 8\end{array}$ & $\begin{array}{r}927 \\
0.6\end{array}$ & $\begin{array}{c}572 \\
0.5-0 \cdot 8\end{array}$ & $\begin{array}{l}907 \\
0.7\end{array}$ & $\begin{array}{c}553 \\
0.5-10 \cdot 0\end{array}$ & 0.203 \\
\hline $\begin{array}{l}\text { Vitamin } \\
(\mathrm{mg})\end{array}$ & Mean, SD & 0.7 & 0.2 & 0.7 & 0.2 & 0.6 & 0.2 & ז & 0.6 & 0.2 & 0.7 & 0.2 & 0.7 & 0.3 & \\
\hline $\begin{array}{l}\text { Vitamin } B_{2} \\
(\mathrm{mg})\end{array}$ & $\begin{array}{l}\text { Median, P25-P75 } \\
\text { Mean, SD }\end{array}$ & $\begin{array}{l}0.4 \\
0.5\end{array}$ & $\begin{array}{c}0.3-0.6 \\
0.3\end{array}$ & $\begin{array}{l}0.4 \\
0.5\end{array}$ & $\begin{array}{c}0.3-0.6 \\
0.3\end{array}$ & $\begin{array}{l}0 \cdot 4 \\
0.5\end{array}$ & $\begin{array}{c}0.3-0.7 \\
0.3\end{array}$ & 0.556 & $\begin{array}{l}0 \cdot 4 \\
0 \cdot 4\end{array}$ & $\begin{array}{c}0.5-0.5 \\
0.3\end{array}$ & $\begin{array}{l}0.5 \\
0.5\end{array}$ & $\begin{array}{c}0.3-0.7 \\
0.3\end{array}$ & $\begin{array}{l}0.5 \\
0.6\end{array}$ & $\begin{array}{c}0.4-0.7 \\
0.3\end{array}$ & 0.007 \\
\hline$\underset{(\mathrm{mg})}{\operatorname{Vitamin} B_{3}}$ & $\begin{array}{l}\text { Median, P25-P75 } \\
\text { Mean, SD }\end{array}$ & $\begin{array}{l}8 \\
8 \cdot 5\end{array}$ & $\begin{array}{c}5 \cdot 8-10 \cdot 8 \\
3 \cdot 9\end{array}$ & $\begin{array}{l}8 \cdot 9 \\
8 \cdot 7\end{array}$ & $\begin{array}{c}6 \cdot 0-10 \cdot 8 \\
3 \cdot 6\end{array}$ & $\begin{array}{l}7 \cdot 6 \\
8 \cdot 7\end{array}$ & $\begin{array}{c}5 \cdot 6-10 \cdot 8 \\
4 \cdot 6\end{array}$ & 0.463 & $\begin{array}{l}8 \cdot 0 \\
8 \cdot 2\end{array}$ & $\begin{array}{c}5 \cdot 3-10 \cdot 7 \\
3 \cdot 5\end{array}$ & $\begin{array}{l}7 \cdot 6 \\
8 \cdot 4\end{array}$ & $\begin{array}{c}5 \cdot 8-10 \cdot 3 \\
3 \cdot 7\end{array}$ & $\begin{array}{l}10 \cdot 2 \\
10 \cdot 2\end{array}$ & $\begin{array}{c}7 \cdot 0-12 \cdot 2 \\
5 \cdot 0\end{array}$ & 0.055 \\
\hline $\begin{array}{l}\text { Vitamin } B_{6} \\
(\mathrm{mg})\end{array}$ & $\begin{array}{l}\text { Median, P25-P75 } \\
\text { Mean, SD }\end{array}$ & $\begin{array}{l}0.4 \\
0.5\end{array}$ & $\begin{array}{c}0.2-0.7 \\
0.5\end{array}$ & $\begin{array}{l}0.4 \\
0 \cdot 6\end{array}$ & $\begin{array}{c}0.2-0.6 \\
0.6\end{array}$ & $\begin{array}{l}0.4 \\
0.5\end{array}$ & $\begin{array}{c}0.2-0.7 \\
0.6\end{array}$ & 0.789 & $\begin{array}{l}0.3 \\
0.5\end{array}$ & $\begin{array}{c}0.1-0.6 \\
0.5\end{array}$ & $\begin{array}{l}0.4 \\
0.5\end{array}$ & $\begin{array}{c}0.2-0.7 \\
0.4\end{array}$ & $\begin{array}{l}0.5 \\
0.6\end{array}$ & $\begin{array}{c}0.4-0.8 \\
0.3\end{array}$ & 0.382 \\
\hline Folate $(\mu \mathrm{g})$ & $\begin{array}{l}\text { Median, P25-P75 } \\
\text { Mean, SD }\end{array}$ & $\begin{array}{r}92 \\
119\end{array}$ & $\begin{array}{c}52-161 \\
92\end{array}$ & $\begin{array}{r}92 \\
120\end{array}$ & $\begin{array}{c}54-162 \\
91\end{array}$ & $\begin{array}{r}92 \\
117\end{array}$ & $\begin{array}{c}48-157 \\
92\end{array}$ & 0.743 & $\begin{array}{r}96 \\
110\end{array}$ & $\begin{array}{l}48-138 \\
76\end{array}$ & $\begin{array}{r}86 \\
120\end{array}$ & $\begin{array}{c}47-167 \\
99\end{array}$ & $\begin{array}{l}129 \\
145\end{array}$ & $\begin{array}{c}60-222 \\
108\end{array}$ & $0 \cdot 186$ \\
\hline$\underset{(\mu \mathrm{g})}{\operatorname{Vitamin} B_{12}}$ & $\begin{array}{l}\text { Median, P25-P75 } \\
\text { Mean, SD }\end{array}$ & $\begin{array}{l}0 \cdot 9 \\
1 \cdot 2\end{array}$ & $\begin{array}{c}0 \cdot 3-1 \cdot 8 \\
1 \cdot 1\end{array}$ & $\begin{array}{l}0 \cdot 9 \\
1 \cdot 1\end{array}$ & $\begin{array}{c}0 \cdot 2-1 \cdot 7 \\
1 \cdot 1\end{array}$ & $\begin{array}{l}0 \cdot 9 \\
1 \cdot 3\end{array}$ & $\begin{array}{c}0 \cdot 4-1 \cdot 9 \\
1 \cdot 1\end{array}$ & 0.499 & $\begin{array}{l}0.6 \\
0.9\end{array}$ & $\begin{array}{c}0 \cdot 1-1 \cdot 1 \\
1 \cdot 0\end{array}$ & $\begin{array}{l}1 \cdot 2 \\
1 \cdot 4\end{array}$ & $\begin{array}{c}0.5-1 \cdot 9 \\
1 \cdot 1\end{array}$ & $\begin{array}{l}1 \cdot 5 \\
1 \cdot 7\end{array}$ & $\begin{array}{c}0.7-2 \cdot 6 \\
1.3\end{array}$ & $<0.001$ \\
\hline $\begin{array}{l}\text { Vitamin C } \\
(\mathrm{mg})\end{array}$ & $\begin{array}{l}\text { Median, P25-P75 } \\
\text { Mean, SD }\end{array}$ & $\begin{array}{l}44 \\
18\end{array}$ & $\begin{array}{c}13-86 \\
87\end{array}$ & $\begin{array}{l}43 \\
73\end{array}$ & $\begin{array}{c}13-103 \\
94\end{array}$ & $\begin{array}{l}44 \\
70\end{array}$ & $\begin{array}{c}16-84 \\
82\end{array}$ & 0.777 & $\begin{array}{l}36 \\
66\end{array}$ & $\begin{array}{c}3-87 \\
89\end{array}$ & $\begin{array}{l}44 \\
70\end{array}$ & $\begin{array}{c}18-83 \\
75\end{array}$ & $\begin{array}{l}50 \\
98\end{array}$ & $\begin{array}{c}25-132 \\
120\end{array}$ & 0.246 \\
\hline Ca (mg) & $\begin{array}{l}\text { Median, P25-P75 } \\
\text { Mean, SD }\end{array}$ & $\begin{array}{l}353 \\
450\end{array}$ & $\begin{array}{c}249-528 \\
327\end{array}$ & $\begin{array}{l}342 \\
435\end{array}$ & $\begin{array}{c}248-521 \\
298\end{array}$ & $\begin{array}{l}360 \\
463\end{array}$ & $\begin{array}{c}262-529 \\
353\end{array}$ & 0.504 & $\begin{array}{l}340 \\
436\end{array}$ & $\begin{array}{c}226-539 \\
338\end{array}$ & $\begin{array}{l}356 \\
452\end{array}$ & $\begin{array}{c}253-504 \\
331\end{array}$ & $\begin{array}{l}391 \\
486\end{array}$ & $\begin{array}{c}283-615 \\
281\end{array}$ & 0.807 \\
\hline $\mathrm{Fe}(\mathrm{mg})$ & $\begin{array}{l}\text { Median, P25-P75 } \\
\text { Mean, SD }\end{array}$ & $\begin{array}{l}13 \\
15\end{array}$ & $\begin{array}{c}10-17 \\
8\end{array}$ & $\begin{array}{l}13 \\
15\end{array}$ & $\begin{array}{c}10-19 \\
8\end{array}$ & $\begin{array}{l}14 \\
16\end{array}$ & $\begin{array}{c}11-17 \\
9\end{array}$ & 0.707 & $\begin{array}{l}13 \\
15\end{array}$ & $\begin{array}{c}10-17 \\
9\end{array}$ & $\begin{array}{l}14 \\
15\end{array}$ & $\begin{array}{c}10-18 \\
8\end{array}$ & $\begin{array}{l}14 \\
15\end{array}$ & $\begin{array}{c}11-17 \\
7\end{array}$ & 0.986 \\
\hline $\mathrm{Zn}(\mathrm{mg})$ & $\begin{array}{l}\text { Median, P25-P75 } \\
\text { Mean, SD }\end{array}$ & $\begin{array}{l}4 \cdot 6 \\
4 \cdot 9\end{array}$ & $\begin{array}{c}3 \cdot 3-6 \cdot 1 \\
2 \cdot 1\end{array}$ & $\begin{array}{l}4 \cdot 6 \\
4 \cdot 9\end{array}$ & $\begin{array}{c}3 \cdot 4-6 \cdot 2 \\
2 \cdot 1\end{array}$ & $\begin{array}{l}4 \cdot 7 \\
4 \cdot 9\end{array}$ & $\begin{array}{c}3 \cdot 2-6 \cdot 1 \\
2 \cdot 2\end{array}$ & 0.941 & $\begin{array}{l}4 \cdot 6 \\
4 \cdot 7\end{array}$ & $\begin{array}{c}3 \cdot 1-5 \cdot 9 \\
1 \cdot 9\end{array}$ & $\begin{array}{l}4 \cdot 8 \\
5 \cdot 1\end{array}$ & $\begin{array}{c}3 \cdot 4-6 \cdot 5 \\
2 \cdot 3\end{array}$ & $\begin{array}{l}4 \cdot 6 \\
5 \cdot 1\end{array}$ & $\begin{array}{c}3 \cdot 4-6 \cdot 1 \\
2 \cdot 2\end{array}$ & 0.369 \\
\hline
\end{tabular}

P25-P75, 25th-75th percentile.

Differences between boys and girls and between low-, middle- and high-SES groups were analysed using multivariate ANOVA adjusted by SES and sex, respectively. 


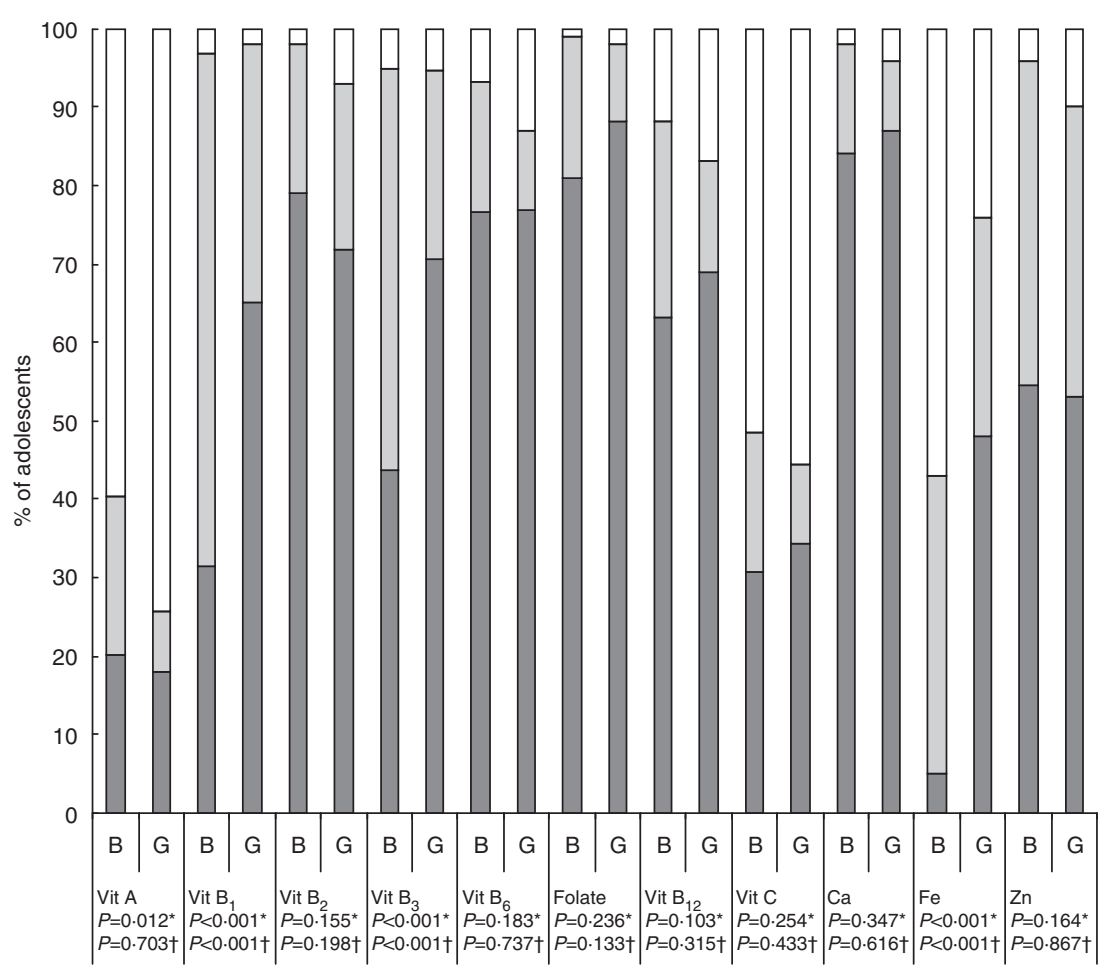

Fig. 1 Proportion (\%) of boys (B; $n$ 108) and girls (G; $n$ 119) reporting vitamin and mineral intakes below the Estimated Average Requirement (EAR; $\square$ ), between the EAR and the Recommended Dietary Allowance (RDA; $\square$ ) and above the RDA ( $\square$ ): adolescents aged 12-16 years, urban Cameroon. *Differences between boys and girls were analysed using the $\chi^{2}$ test; †differences (below EAR $v$. above EAR) between boys and girls were analysed using binary logistic regression

of girls reported cooking. Adolescents with low SES spent less time $(\mathrm{min} / \mathrm{d})$ eating than adolescents with high SES: 88 (sD 25.6) v. 102 (SD 28.2), respectively ( $P=0 \cdot 007$ ).

Several significant positive correlations ranging from 0.502 to 0.874 (Pearson correlation coefficients) were found between $\mathrm{EI}_{\mathrm{rep}}$ and protein; fat and carbohydrate; protein and carbohydrate; protein and $\mathrm{Zn}$; fat and vitamin $\mathrm{A}$; vitamins $\mathrm{B}_{2}$ and $\mathrm{B}_{12}$; folate and vitamin $\mathrm{B}_{6} ; \mathrm{Fe}$ and vitamin $\mathrm{C}$; and $\mathrm{Ca}$ and $\mathrm{Fe}$.

Binary logistic regression analysis did not shown any significant relationship between vitamins $A, B_{1}, B_{2}, B_{3}, B_{6}$, $\mathrm{B}_{12}$ and $\mathrm{C}$, folate, $\mathrm{Ca}, \mathrm{Fe}, \mathrm{Zn}$ and PAL.

\section{Discussion}

To our knowledge the present study is the first to assess energy, macronutrient and micronutrient intakes and physical activity among adolescents in Cameroon. The present study included urban adolescents only since changes in dietary habits and lifestyle are more pronounced in urban than rural areas ${ }^{(11,13)}$.

Overall, the proportion of inadequate intake was high among the adolescents in the present study. This is in accordance with other dietary studies conducted in developing countries that have reported a significant percentage of adolescents with an intake below recommendations ${ }^{(4,5,7,22,23)}$. In the present study, the reported energy and nutrient intakes were generally lower among the adolescents with low SES than among those with high SES although this was significant only for fat and vitamins $B_{2}$ and $B_{12}$. One reason for this inequality is that the adolescents with low SES spent less time eating than those with high SES because of poverty and the fact that many people live in the same household. Poor access to food due to poverty was described in our previous study and in several studies in developing countries, and low SES has been associated with nutrient deficiencies among adolescents ${ }^{(2,4,5,7,9,24)}$.

The lower fat intake among adolescents with low SES compared with those with high SES confirms the results of a previous study in Cameroon, where low fat intake was found among households with low SES ${ }^{(1)}$. Palm oil, which is the main source of fat, may not always be available to adolescents with low SES due to a lack of money. Other fat-rich foods such as butter, milk and cheese are seldom consumed since they are expensive, not always available and considered as luxury foods ${ }^{(1,2)}$.

Somewhat surprisingly, protein intake was not significantly different among the adolescents with low SES and high SES. This could be because the price of meat was high in Yaoundé city during the period when the study was conducted, making meat unaffordable to most people.

The low mean intakes of vitamins $\mathrm{B}_{2}$ and $\mathrm{B}_{12}$, as well as the large proportion of low-SES adolescents with vitamin $B_{2}$, $\mathrm{B}_{3}, \mathrm{~B}_{6}, \mathrm{~B}_{12}$ and folate intakes below the EAR, indicate 


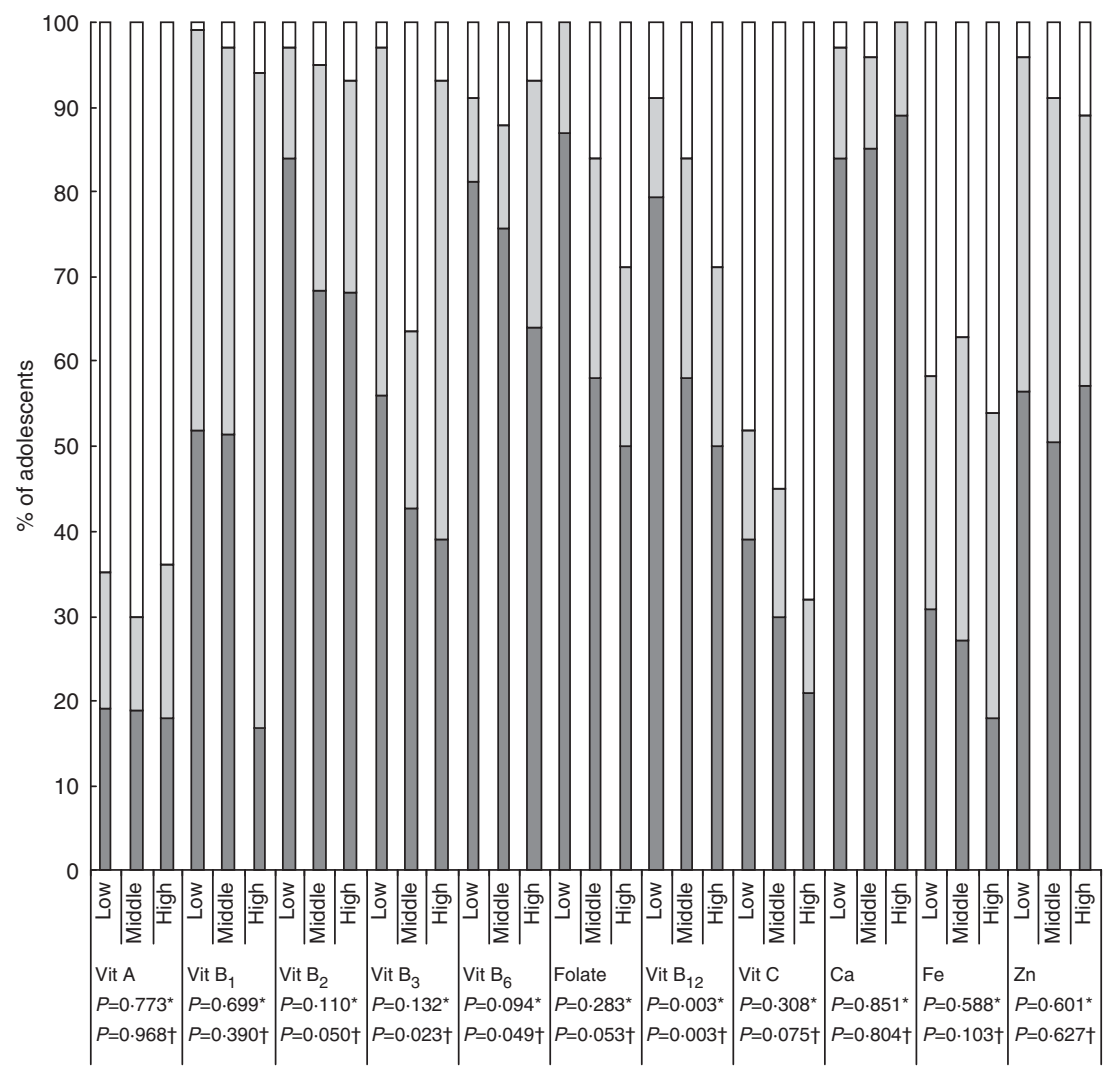

Fig. 2 Proportion (\%) of adolescents reporting vitamin and mineral intakes below the Estimated Average Requirement (EAR; $\square$ ), between the EAR and the Recommended Dietary Allowance (RDA; $\square$ ) and above the RDA ( $\square$ ) in groups with low ( $n$ 94), middle $(n 105)$ and high ( $n$ 28) socio-economic status (SES): boys and girls aged 12-16 years, urban Cameroon. *Differences between SES groups were analysed using the $\chi^{2}$ test; †differences (below EAR $v$. above EAR) between SES groups were analysed using binary logistic regression

poor food variety. The large proportion of girls below the EAR for vitamins $B_{1}$ and $B_{3}$ also indicates a diet rich in refined maize and cassava porridges. An explanation is that carbohydrate-rich foods (maize and cassava porridges) are the main energy sources and represent the main part of the household budget for food in Cameroon, especially among households with low $\mathrm{SES}^{(23)}$. In addition, meat and fish, which are rich in vitamins $A, B_{1}, B_{2}$ and $\mathrm{B}_{12}$, are not always consumed by households with low income because of the high $\operatorname{cost}^{(23)}$. Previously we found that adolescents with low SES were not accustomed to eating meat and fish due to the high $\operatorname{cost}^{(2,11)}$. A national survey in Cameroon showed that the household 'meat' budget of families with high income was 119 times that of low-income families ${ }^{(1)}$. Other foods rich in vitamins $\mathrm{A}, \mathrm{B}_{1}, \mathrm{~B}_{2}$ and $\mathrm{B}_{12}$ such as butter, milk products and eggs are also seldom consumed since they are expensive and are not part of the food habits ${ }^{(1,2)}$

A higher proportion of boys were below the RDA for vitamin A than girls in the present study. In South Africa, a study among black adolescents in urban areas found that $78 \%$ had an intake below the RDA for vitamin $A^{(25)}$. Vitamin A inadequacy is a problem in Cameroon and is explained by low intake of vitamin A-rich food, inappropriate cooking methods and seasonal food availability ${ }^{(1)}$. Palm oil and green leaves are the major sources of vitamin $\mathrm{A}$ and the content of vitamin $\mathrm{A}$ as well as other vitamins decreases with commonly used cooking methods such as bleaching palm oil by heating, and by boiling, squeezing and drying green leaves in the $\operatorname{sun}^{(20)}$. Vitamin A-rich foods such as carrots, papaya, water melon and mangoes are not always consumed because of the high cost, seasonal availability and the fact that they are not considered as food ${ }^{(1,2,5,22,23)}$.

Boys and girls had similar median Fe intake but, as the requirements of girls are much higher due to menstruation, this resulted in a tenfold higher proportion of girls below the EAR compared with boys. Low Fe intake has been related to Fe deficiency among women and children in Cameroon ${ }^{(23)}$. This is probably due to a lack of awareness that girls need to eat more Fe-rich foods than boys because of menstruation. Moreover, Fe-rich foods such as meat and fish are expensive and when available in some families, are only for the father ${ }^{(23)}$.

The high proportion of inadequate nutrient intake in the present study may be caused by true low intake, underreporting of food intake, or a combination of the two. Misreporting of energy intake is a common problem in most 
dietary surveys including the present study ${ }^{(18,22,26,27)}$. Under-reporting and over-reporting were both common in the present study. The proportion of adolescents classified as under-reporters was higher in our study compared with a Swedish study among adolescents (19\% under-reporting $v$. $41 \%$ in the present study) and more similar to the proportion in a Canadian study among adolescents $(50 \%)^{(26,27)}$. The high proportion of over-reporters in the present study may be due to a desire to demonstrate affluence. Previously we found that eating food was a sign of wealth: the more food you ate the better-off you were, and overweight was described as beautiful ${ }^{(2)}$.

Boys reported a lower $\mathrm{EI}_{\mathrm{rep}}: \mathrm{EE}_{\mathrm{rep}}$ and were more often classified as under-reporters than girls. This could be explained by the fact that the boys were not as aware of foods eaten as the girls, who were more often involved in food preparation at home. Also, boys might eat less food than they require due to gender differences in physical activity. Girls over-reported more than boys. This might be explained by the tradition that provision of food, especially to girls and women, is a sign of good care from the family. The boys were leaner than the girls and more often involved in heavy activities as confirmed by the higher $\mathrm{EE}_{\mathrm{rep}}$, PAL and football playing frequency among boys. Girls had a lower PAL than boys, probably because they were involved in lighter activities such as cooking, doing homework and other household activities.

There are several sources of errors in the present study which make the interpretation of our results complicated. First, a small sample size with stratification by sex and SES could be a limitation and a possible reason for few significant differences between boys and girls and between SES groups. Second, information about food ingredients and recipes was difficult to obtain. The same problem of inaccurate information about food ingredients was described among adults in Cameroon and Mali ${ }^{(13,22)}$. To minimize this error, information about food ingredients and recipes were required from girls, vendors and restaurants. Third, information about food portions and memory bias could have contributed to under- and overreporting. Therefore a picture booklet was developed, containing pictures of the most commonly consumed foods. In addition, food price, real food portions and household measures were used. Lack of a specific food composition table and nutrition software program for Cameroon might have affected the estimation of nutrient intake. Therefore, laboratory analyses of the nutrient content of four main foods were conducted. Fourth, lack of specific values for nutrient requirements for the Cameroonian adolescents might have affected the proportion of the adolescents with inadequate nutrient intake. To minimize this error, WHO nutrient requirement values for developing countries were used as the RDA. The challenges encountered in the present study are common in most dietary surveys and we believe that the problems were dealt with in a suitable manner. To our knowledge, few validation studies of food intake have been carried out in sub-Saharan Africa. Validation is of great importance and should be carried out in future studies. In South Africa, validation of an FFQ has been carried out ${ }^{(28)}$. Despite these issues just mentioned, the present study is important since data on adolescent food intake in Cameroon are largely missing. Our results could be applicable among school adolescents in other urban cities in Cameroon as well as in several cities of other African countries.

\section{Conclusions}

A high proportion of boys and girls reported inadequate intakes. However under- and over-reporting were also very common. Boys had higher PAL, EE and underreported EI more than girls. Inadequate nutrient intake was more frequently reported by the adolescents with low SES than those with high SES.

\section{Acknowledgements}

Major funding for this study came from the Umeå Global Health Center, Umeå University, Sweden. Additional funding was from the NESTLE Nutrition Paediatric Program scholarships of Vevey, Switzerland. The authors report no conflict of interest. L.N.D. planned and executed the study, analysed the data and prepared the initial, revised and final versions of the manuscript. U.J., C.L. and A.H. participated in the initial, revised and final versions of the manuscript. H.S. participated in the statistical analysis. We acknowledge the adolescents who participated in the study and the headmasters of the schools. We thank the nurses and the physician who collected the data. Additionally we thank Dr Lena Håglin, Erik Poortvliet and Dr Fikru Tesfaye for review of the manuscript.

\section{References}

1. Direction de la Statistique et de la Comptabilité Nationale (2000) La consommation alimentaire au Cameroun en 1996. Données de l'enquête Camerounaise auprès de ménages. Yaoundé: Ministère des Finances.

2. Dapi NL, Omoloko C, Janlert U et al. (2007) 'I eat to be happy, to be strong and to live'. Perceptions of rural and urban adolescents in Cameroon, Africa. J Nutr Educ Behav 39, 320-326.

3. Mahan LK, Escott-Stump S \& Krause MV (2004) Krause's Food, Nutrition and Diet Therapy, 10th ed. Philadelphia, PA: W.B. Saunders.

4. Ahmed F, Zareen M, Khan MR et al. (1998) Dietary pattern, nutrient intake and growth of adolescents school girls in urban Bangladesh. Public Health Nutr 1, 83-92.

5. Ijarotimi OS (2004) Evaluation of energy and micronutrients intake of Nigerian adolescent females: a case study of institutionalized secondary schools in Akure south local Government area, Ondo state, Nigeria. Pakistan J Nutr 3, 250-253. 
6. Gibson RS (2005) Principles of Nutritional Assessment, 2nd ed. Oxford: Oxford University Press.

7. Serra-Majem L, Ribas L, Perez-Rodrigo C et al. (2002) Determinants of nutrients intake among children and adolescents: results from the enKid study. Ann Nutr 46, 31-38.

8. DiMeglio G (2000) Nutrition in adolescence. Pediatr Rev 21, 32-38.

9. Ogechi UP, Akhakhia OI \& Ugwunna UA (2007) Nutritional status and energy intake of adolescents in Umuahia urban, Nigeria. Pakistan J Nutr 6, 641-646.

10. Food and Agriculture Organization of the United Nations/ World Health Organization/United Nations University (2001) Human Vitamin and Mineral Requirements. Report of a Joint FAO/WHO Expert Consultation, Bangkok, Thailand. Geneva: WHO.

11. Dapi NL, Nouedoui C, Janlert U et al. (2005) Adolescents' food habits and nutritional status among in urban and rural areas in Cameroon, Africa. Scand J Nutr 49, 151-158.

12. Dapi NL, Janlert U, Stenlund H et al. (2009) Socioeconomic and gender differences in adolescents nutritional status in urban Cameroon, Africa. Nutr Res 9, 313-319.

13. Mennen LI, Mbanya JC, Cade J et al. (2000) The habitual diet in rural and urban Cameroon. Eur J Clin Nutr 54, 150-154.

14. World Health Organization (1970) Food Composition Table for Africa. Rome: FAO.

15. Barikmo I, Ouatara F \& Oshaug A (2004) Food Composition Table for Mali. Oslo: Akershus University College.

16. Ainsworth BE, Haskell WL, Whitt MC et al. (2000) Compendium of physical activities: an update of activity codes and MET intensities. Med Sci Sport Exerc 32, 9 Suppl., S498-S504.

17. Food and Agriculture Organization of the United Nations/ World Health Organization/United Nations University (2001) Human Energy Requirements. Report of a Joint FAO/WHO/UNU Expert Consultation, Rome, 17-24 October 2001. Rome: FAO.

18. Black AE (2000) Critical evaluation of energy intake using the Goldberg cut-off for energy intake:basal metabolic rate.
A practical guide to its calculation, use and limitations. Int $J$ Obes Relat Metab Disord 24, 1119-1130.

19. Latham MC (1979) Nutrition Humaine en Afrique tropicale. Rome: FAO.

20. Savage KF \& Burges A (2006) Nutrition for Developing Countries, 2nd ed. Oxford: Oxford University Press.

21. Prentice A, Branca F, Decsi T et al. (2004) Energy and nutrient dietary reference values for children in Europe: methodological approaches and current nutritional recommendations. Br J Nutr 92, Suppl. 2, S83-S146.

22. Vähätalo L, Mikkilä V \& Räsänen L (2005) Schoolchildren's food consumption and dietary intake during the dry season in north-west Namibia. Int J Food Sci Nutr 56, 367-375.

23. UNICEF/World Health Organization/Helen Keller Worldwide (2000) Enquête nationale sur la carence en vitamine $A$ et l'anémie. Yaoundé: UNICEF.

24. Delisle H, Chandra MV \& Benoist B (2001) Should Adolescents be Specifically Targeted for Nutrition in Developing Countries? To Address Which Problems, and How? Geneva: WHO.

25. MacKeown JM, Pedro TM \& Norris SA (2007) Energy, macronutrient intake among a true longitudinal group of South African adolescents at two interceptions (2000 and 2003): the Birth-to-Twenty (Bt20) study. Public Health Nutr 10, 635-643.

26. Vance VA, Woodruff SJ, McCargar LJ et al. (2009) Selfreported dietary energy intake of normal weight, overweight and obese adolescents. Public Health Nutr 12, 222-227.

27. Vågstrand K, Barkeling B, Forslund HB et al. (2007) Eating habits in relation to body fatness and gender in adolescents results from the SWEDES study. Eur J Clin Nutr 61, $517-525$.

28. MacIntyre UE, Venter CS \& Vorster HH (2001) A culturesensitive quantitative food frequency questionnaire used in an African population: 2. Relative validation by 7-day weighed records and biomarkers. Public Health Nutr $\mathbf{4}$, 63-71. 